\title{
Hemoglobin Yakima: II. High Blood Oxygen Affinity Associated with Compensatory Erythrocytosis and Normal Hemodynamics*
}

\author{
Miles J. Novy, $\ddagger$ Miles J. Edwards, and James Metcalfe $\S$ \\ (From the Heart Research Laboratory and Division of Chest Diseases, Department of Medicine, \\ University of Oregon Medical School, Portland, Oregon)
}

\begin{abstract}
Erythrocytosis without clinical illness was noted in a man and his two daughters. Their blood contained approximately $62 \%$ hemoglobin A and $38 \%$ a new hemoglobin, designated hemoglobin Yakima. The oxygen affinity of whole blood from each subject was greatly increased and hemeheme interactions were impaired. At $37^{\circ} \mathrm{C}$ and a plasma $\mathrm{pH}$ of 7.40 , the oxygen pressure required to produce $50 \%$ saturation of hemoglobin with oxygen was only $12 \mathrm{~mm} \mathrm{Hg}$ as compared with a normal of $26 \mathrm{~mm} \mathrm{Hg}$. The high oxygen affinity of this blood is attributed to the presence of hemoglobin Yakima; and the increased oxygen affinity was shown to be characteristic of the isolated abnormal hemoglobin. A Bohr effect was present in hemoglobin Yakima.

Arterial oxygen pressure, oxygen consumption, and cardiac output at rest were normal. With respect to oxygen delivery to tissues, the increased hemoglobin concentration appears to be the major compensation for the marked displacement of the oxygen-hemoglobin equilibrium curve, although other factors may contribute. The finding of high normal quantities of erythropoietin in the urine is consistent with this degree of erythrocytosis.
\end{abstract}

\section{Introduction}

In order to function effectively in oxygen transport, hemoglobin must be able to combine with oxygen at pressures found in the lungs and be

\footnotetext{
* Received for publication 16 May 1967 and in revised form 23 June 1967.

Supported by Training Grant No. HE 5499, Research Grant No. HE 06042, and Cardiovascular Program Project Grant No. HE 06336 of the National Heart Institute and by funds from the National Institute of Child Health and Human Development.

Presented in part at the Twentieth Annual Meeting of the Western Society for Clinical Research, 26 January 1967, at Carmel, Calif.

$\ddagger$ Research Associate, National Institute of Child Health and Human Development. Present address: Dept. of Surgery, Boston University School of Medicine, Boston, Mass.

$\S$ Professor of Medicine, Oregon Heart Association Chair of Cardiovascular Research. Address requests for reprints to Dr. James Metcalfe, Heart Research Laboratory, University of Oregon Medical School, Portland, Oreg. 97201.
}

able to deliver oxygen to tissues at pressures adequate for diffusion to intracellular sites of utilization. Normal hemoglobin is well designed for both these functions as expressed by the Bohr effect, the midposition of the oxygen-hemoglobin equilibrium curve and its sigmoid shape (a measure of heme-group interactions).

More than 70 human hemoglobin variants have been reported (1), but only a few have been associated with altered oxygen-binding properties. A new hemoglobin, designated hemoglobin $\mathrm{Ya}$ kima, has been found to constitute approximately $38 \%$ of the total hemoglobin in three healthy members of one family (2). Each of the three individuals, heterozygous for hemoglobin Yakima, possessed a significant erythrocytosis associated with a high oxygen affinity of the blood.

Significant alterations in the oxygen-carrying properties of blood might evoke compensatory responses in other systems concerned with oxygen transport and utilization. Our study was de- 
signed to characterize the altered oxygen-binding properties of hemoglobin Yakima and to investigate its possible hemodynamic and metabolic consequences.

\section{Methods}

The family pedigree of these subjects, the results of hematologic studies, and the details of chemical characterization of hemoglobin Yakima are reported by Jones, Osgood, Brimhall, and Koler (2). Designation of the propositus and the two other subjects in our present study conforms to the schema of those authors.

Oxygen equilibria of whole blood. For studies of the oxygen-hemoglobin equilibria, venous blood was obtained without stasis. A solution of heparin $(10 \mathrm{mg} / \mathrm{ml})$ saturated with sodium fluoride was used to fill the dead space of each withdrawal syringe. Immediately after withdrawal of the blood, we began in vitro oxygen-hemoglobin equilibrium studies using two different techniques which have been described in detail in previous publications and which have shown excellent agreement in our laboratory $(3,4)$. Because of the high oxygen affinity of blood from these patients, complete deoxygenation of blood was difficult to achieve. We, therefore, measured the oxygen concentration in the "deoxygenated" samples by the Van Slyke micromanometric apparatus and made the necessary corrections in our calculations of per cent of hemoglobin saturation by the "mixing technique"
(4). Partial pressure of oxygen in millimeters mercury $\left(\mathrm{Po}_{2}\right)$ and $\mathrm{pH}$ of the mixture were measured with Radiometer electrodes at $37^{\circ} \mathrm{C}$. The occurrence of hemolysis after tonometry was excluded by centrifugation and visual examination of the plasma. On one occasion, in vivo data were also obtained by measurement of oxygen saturation, $\mathrm{pH}$, and $\mathrm{PO}_{2}$ of blood taken from the brachial artery and the antecubital vein.

The hemoglobin concentration of each blood sample was determined by a spectrophotometric method (5). Oxygen capacity was determined gasometrically after oxygenation at $37^{\circ} \mathrm{C}(3)$. Methemoglobin concentrations in blood and in hemoglobin solutions were measured by a modification of the method by Evelyn and Malloy (6).

Oxygen equilibria of hemoglobin solutions. Hemoglobin solutions were prepared from lysed red cells after extraction of stroma and lipid with toluene. Separation of hemoglobin Yakima and hemoglobin A was accomplished by column chromatography as described by Jones and coworkers (2). Each 5-10 $\mathrm{ml}$ aliquot of hemoglobin $A$ and hemoglobin Yakima and of unfractionated hemoglobin solutions (62\% A and $38 \%$ Yakima) was dialyzed for 24 hours against 1 liter of $0.05 \mathrm{M}$ potassium phosphate buffer. Oxygen-hemoglobin equilibria were determined by the "mixing technique" at $37^{\circ} \mathrm{C}, \mathrm{pH} 6.45-6.50$, and with hemoglobin concentrations of $3.5-4.5 \mathrm{~g} / 100 \mathrm{ml}$. Similar aliquots of pure hemoglobin $\mathrm{A}$ and hemoglobin Yakima were dialyzed overnight against $0.15 \mathrm{M} \mathrm{NaCl}$. Changes in $\mathrm{pH}$ after complete oxygenation by $100 \%$ oxygen and virtual deoxygenation by prepurified nitrogen

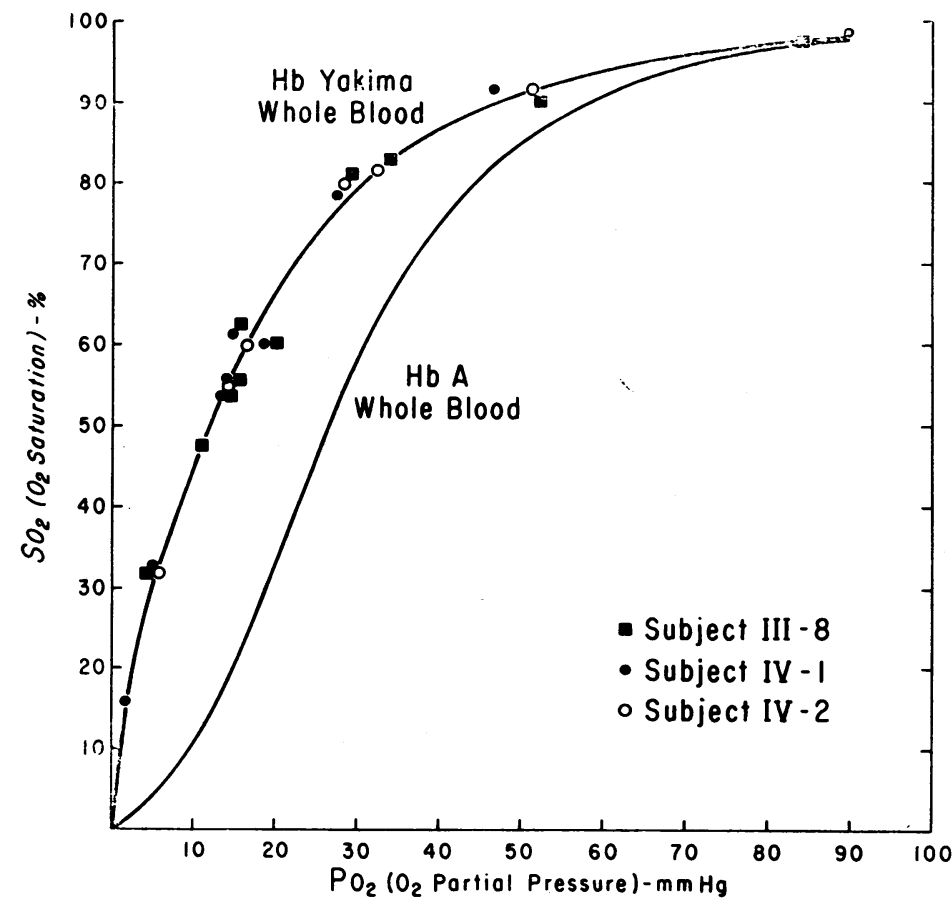

Fig. 1. OXYGEN-HEMOgLOBIN EQUILIBRIUM OF BLOOD AT $37^{\circ} \mathrm{C}$ FROM THE PROPOSITUS (III-8) AND HIS TWO DAUGHTERS (IV-1, IV-2) COMPARED WITH THAT OF NORMAL ADULT BLOOD. 
TABLE I

Measured values of $\mathrm{pH}, \mathrm{PCO}_{2}, \mathrm{PO}_{2}$ at $37^{\circ} \mathrm{C}$ and percentage of oxygen saturation of blood of three subjects (III-8, $I V-1, I V-2)$ with $38 \%$ hemoglobin Yakima

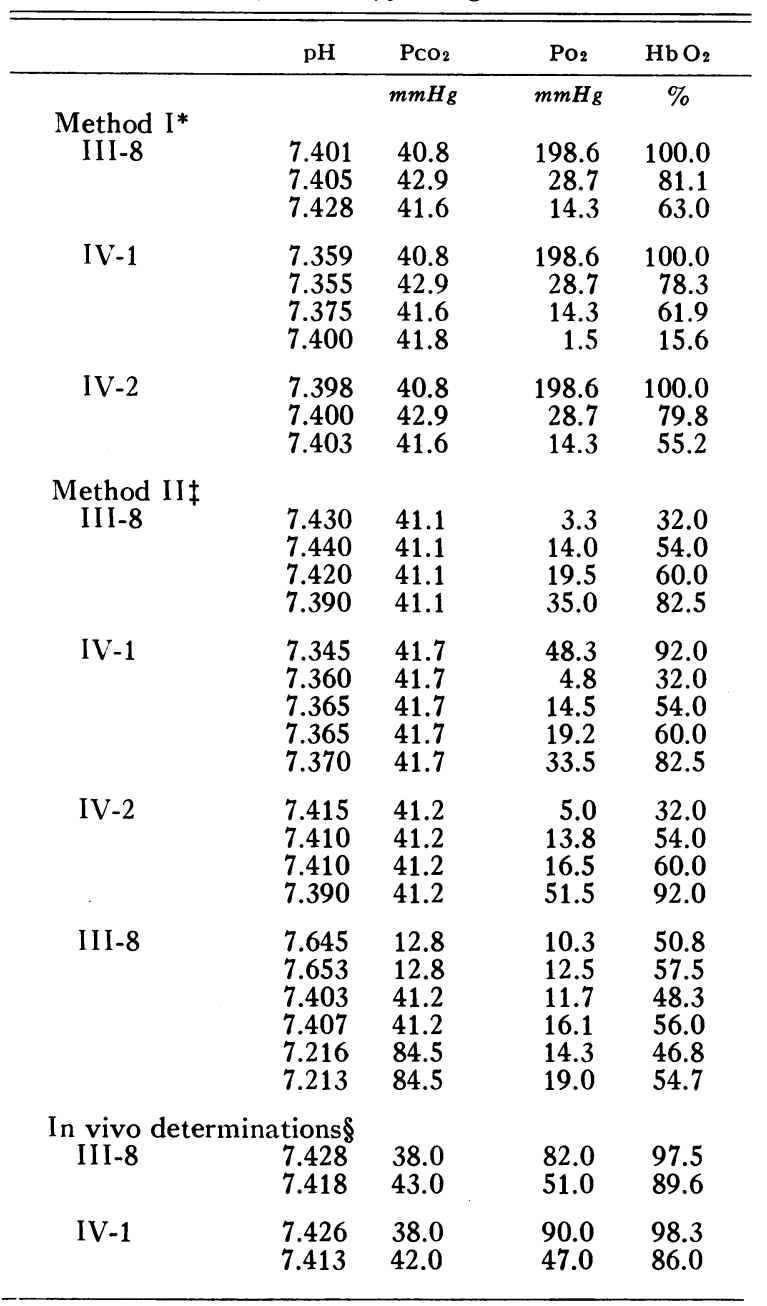

* Method I: Per cent of oxygen saturation $\left(\mathrm{Hb} \mathrm{O}_{2} \%\right.$ ) calculated from measured gas concentrations in blood by Van Slyke manometric apparatus.

$\ddagger$ Method II : $\mathrm{Hb} \mathrm{O}_{2} \%$ determined by volumetric mixing of oxygenated and deoxygenated blood and $\mathrm{PO}_{2}$ measured by electrode.

$\S \mathrm{PCO}_{2}$ calculated from whole blood $\mathrm{CO}_{2}$ content.

were compared in the two isolated hemoglobins for an estimate of the Bohr effect.

Hemodynamic and metabolic studies. Studies of hemodynamic function and metabolic rate were performed on the propositus (subject III-8) and his two daughters (subjects IV-1 and IV-2). After an overnight fast, each subject was allowed to rest in the supine position without sedation. A transcutaneous brachial artery catheter was inserted. A cephalic vein was cannulated with a 17gauge polyethylene cannula for injection of $5 \mathrm{mg}$ of indocyanine green dye followed by isotonic saline. Cardiac output was measured by the indicator-dilution method
(7) ; dye concentration in arterial blood was measured continuously with a Colson densitometer and Honeywell recorder. Brachial artery pressure was recorded with a Statham P23AA strain gauge. After stabilization was achieved, total body oxygen consumption was measured (8). Expired air was analyzed for $\mathrm{O}_{2}$ and $\mathrm{CO}_{2}$ by the technique of Scholander (9). During collection of the expired air, cardiac output was measured. Duplicate measurements of cardiac output, oxygen consumption, heart rate, and brachial artery pressure were made at 10 -min intervals and the results were averaged. Arterial blood samples were analyzed for $\mathrm{pH}_{r} \mathrm{Po}_{2}$, and oxygen and carbon dioxide concentrations. Arterial-venous blood oxygen concentration differences were calculated from the average cardiac output and oxygen consumption by the Fick equation. We estimated mixed venous blood oxygen tension from the patient's oxygen-hemoglobin equilibrium curve. Normal values for our laboratory are: cardiac index, 2.4-3.4 liters/min per $\mathrm{m}^{2}$; arterial-venous oxygen concentration difference, less than 5.2 volumes/ $100 \mathrm{ml}$; arterial blood oxygen saturation, 95-98\%.

\section{Results}

Oxygen equilibria of whole blood. Blood samples from the propositus and his two daughters showed an unusually high oxygen affinity (Fig. 1, Table I). Each point represents the average of duplicate measurements. In our laboratory, normal adult whole blood at $\mathrm{pH} 7.40$ and $37^{\circ} \mathrm{C}$ is half-saturated with oxygen at a pressure $\left(\mathrm{P}_{\tilde{5} 0}\right)$ of $26.0 \mathrm{~mm} \mathrm{Hg} \pm 0.5 \mathrm{~mm} \mathrm{Hg}$ (SD). Blood from each of the three individuals showed a $\mathrm{P}_{50}$ of approximately $12 \mathrm{~mm} \mathrm{Hg}$. At $54 \%$ saturation the mean $\mathrm{Po}_{2}$ was $14.1 \mathrm{~mm} \mathrm{Hg} \pm 0.5 \mathrm{~mm} \mathrm{Hg}$ ( $\mathrm{SD}$ ). The oxygen-hemoglobin equilibrium curve is hyperbolic, indicating significant impairment of hemeheme interaction. According to Hill's equation: $\log (\mathrm{y} / 100-\mathrm{y})=n \log \mathrm{Po}_{2}+\log \mathrm{K}$, where $y$ is the per cent of oxyhemoglobin and $\mathrm{K}$ is a constant, $n$ is an expression of heme-heme interactions ( $n$ $=1=$ no interactions). The $n$ value calculated from our data (by the method of least squares) in the range of $15-82.5 \%$ saturation was 1.1 for blood that contained $38 \%$ hemoglobin Yakima and $62 \%$ hemoglobin A. Normal blood has an $n$ value of 2.5-3.0. A near-normal Bohr effect factor $(\Delta \log$ $\left.\mathrm{Po}_{2} / \Delta \mathrm{pH}=-0.44\right)$ in the region of $50 \%$ saturation was found in whole blood from one of our subjects (III-8). An average factor of -0.52 was calculated over the range of $15-82.5 \%$ saturation after data from all subjects were pooled.

Methemoglobin in whole blood was excluded by spectrophotometric examination of freshly drawn 
blood and by comparison of total hemoglobin measured as cyanmethemoglobin and oxygen capacity by Van Slyke gasometric methods.

Oxygen equilibria of hemoglobin solutions. Hemoglobin fractions isolated by column chromatography were $98 \%$ pure. Hemolysates exposed to chromatography showed an increased propensity to methemoglobin formation during dialysis and tonometry, in contrast to unfractionated hemoglobin solutions. In repeated studies, however, the concentrations of methemoglobin were the same in both hemoglobin Yakima and hemoglobin A solutions and comprised $20-28 \%$ of the total hemoglobin. Oxygen equilibria of hemoglobin Yakima and hemoglobin A were studied on the same day under identical in vitro conditions in order to insure comparative validity.

Absorption spectra in the ultraviolet and visible spectral regions showed no evidence of denaturation of the individual hemoglobin fractions. Evidence of the functional integrity of unoxidized hemoglobin was its ability to undergo reversible oxygenation and deoxygenation during tonometry and mixing. It is evident from Fig. 2 that the high oxygen affinity of whole blood is attributable to the abnormal hemoglobin. Isolated hemoglobin A from these individuals had a $\mathrm{P}_{50}$ of approximately $26 \mathrm{~mm} \mathrm{Hg}$, whereas the $\mathrm{P}_{50}$ of hemoglobin Yakima was approximately $5 \mathrm{~mm} \mathrm{Hg}$. Unfractionated hemolysate (free of methemoglobin) showed an intermediate $\mathrm{P}_{50}$ of $14 \mathrm{~mm} \mathrm{Hg}$, although whole hemolysate from normal controls had a $\mathrm{P}_{50}$ of $34 \mathrm{~mm} \mathrm{Hg}$ under the same conditions. We calculated $n$ in Hill's equation for each hemoglobin solution. Pure hemoglobin Yakima had an $n$ of 1.0 (indicating no heme-heme interactions); the $n$ of unfractionated hemolysate was 1.1. Chromatographically separated hemoglobin A from these subjects had an $n$ of 2.2 , whereas the $n$ of whole hemolysate from normal controls was 2.7 .

The $\mathrm{P}_{50}$ and $n$ values of normal whole hemolysate are comparable with data of Nechtman and Huisman (10), which were obtained under conditions of temperature, buffer, and hemoglobin concentration similar to ours but with conventional spectrophotometric techniques. The lower values of $\mathrm{P}_{50}$ and $n$ found in chromatographically separated hemoglobin $\mathrm{A}$ are probably related to the

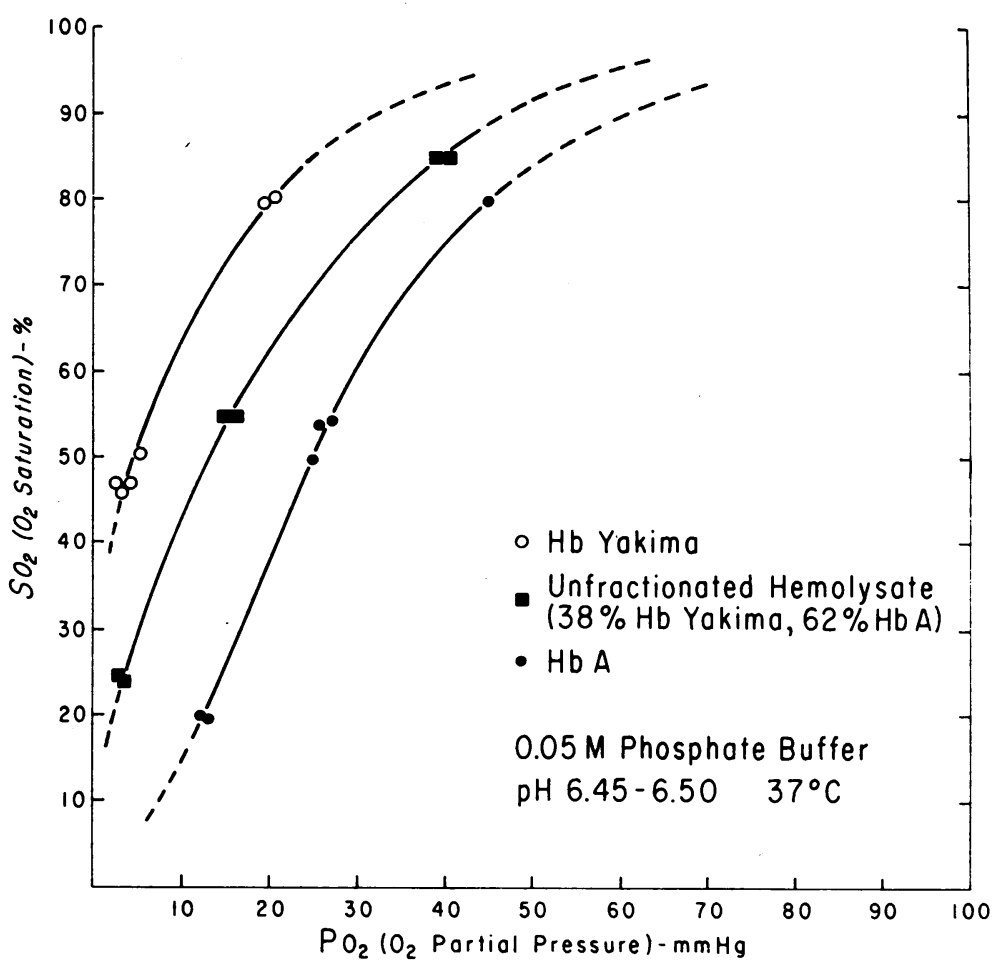

FIG. 2. COMPARISON OF OXYGEN-HEMOGLOBIN EQUILIBRIA OF HEMOGLOBIN SOLUTIONS. 
TABLE II

A comparison of change in $\mathrm{pH}$ in hemoglobin Yakima* and hemoglobin $A^{*}$ upon deoxygenation (Bohr effect) in $0.15 \mathrm{M} \mathrm{NaCl}$

\begin{tabular}{ll}
\hline \multicolumn{2}{c}{$\mathrm{pH}$} \\
\hline Hemoglobin Yakima \\
Oxygenated & $7.471 \pm 0.002$ \\
Deoxygenated & $7.572 \pm 0.004$ \\
Hemoglobin A & \\
Oxygenated & $7.440 \pm 0.001$ \\
Deoxygenated & $7.569 \pm 0.005$ \\
\hline
\end{tabular}

* Total hemoglobin concentration $3.6 \pm 0.1 \mathrm{~g} / 100 \mathrm{ml}$ the data shown are mean values of three determinations.

presence of methemoglobin and are in accord with the observations of Darling and Roughton (11).

A qualitative comparison of the Bohr effect in isolated hemoglobin Yakima and in hemoglobin A is given in Table II. Methemoglobin concentrations before and after deoxygenation remain the same in both hemoglobin fractions.

Hemodynamic and metabolic studies. Arterial oxygen saturations, rates of oxygen consumption, and cardiac indexes were within normal ranges (Tables I and III). Normal acid-base status was present as indicated by normal blood $\mathrm{pH}$ values at approximately $40 \mathrm{~mm} \mathrm{Hg} \mathrm{PcO}_{2}$.

The oxygen concentration in arterial blood $\left(\mathrm{Ca}_{\mathrm{O}_{2}}\right)$ was 23.9 volumes $/ 100 \mathrm{ml}$ for subject III-8 and 22.0 volumes $/ 100 \mathrm{ml}$ for subject IV-1. Arterial $\mathrm{pH}$ was 7.428 and 7.426 , respectively. Calculated values for mixed venous blood at $\mathrm{pH} 7.40$

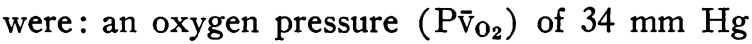

TABLE III

Resting hemodynamic and metabolic studies in three subjects with $38 \%$ hemoglobin Yakima

\begin{tabular}{|c|c|c|c|}
\hline & III-8 & IV-1 & IV-2 \\
\hline Body surface area, $m^{2}$ & 2.22 & 1.86 & 1.76 \\
\hline $\begin{array}{l}\text { Body weight, } \mathrm{kg} \\
\text { Cardiac index, } \\
\text { liters } / \text { min per } \mathrm{m}^{2}\end{array}$ & $\begin{array}{l}93.2 \\
2.58\end{array}$ & $\begin{array}{l}71.8 \\
3.32\end{array}$ & $\underline{61.8}$ \\
\hline $\begin{array}{l}\text { Oxygen consumption, } \\
\mathrm{ml} / \mathrm{min} \text { per } \mathrm{m}^{2}\end{array}$ & 125 & 125 & 117 \\
\hline $\begin{array}{l}\text { Mixed venous } \mathrm{Po}_{2} \\
\quad m m \mathrm{Hg}\end{array}$ & 34 & 35 & 一 \\
\hline $\mathrm{RQ}$ (expired air) & 0.77 & 0.60 & 0.74 \\
\hline Basal metabolic rate & -6 & +3 & -8 \\
\hline Heart rate, beats/min & 58 & 67 & 66 \\
\hline Blood pressure, $\mathrm{mm} \mathrm{Hg}$ & $116 / 72$ & $130 / 74$ & $115 / 70$ \\
\hline $\begin{array}{l}\text { Oxygen capacity, } \\
\text { volumes } 100 \mathrm{ml}^{*}\end{array}$ & 24.2 & 22.1 & \\
\hline $\begin{array}{l}\text { Hemoglobin concentra- } \\
\text { tion, } \mathrm{g} / 100 \mathrm{ml}\end{array}$ & $18.3-18.9$ & $17.0-17.7$ & 17.2 \\
\hline
\end{tabular}

* Van Slyke determinations at time of cardiac output study.

$\ddagger$ Variation during 2-month interval. and an oxygen concentration $\left(\mathrm{C}_{\mathrm{O}_{2}}\right)$ of 19.1 volumes $/ 100 \mathrm{ml}$ for subject III-8; and $\mathrm{P} \overline{\mathrm{v}}_{\mathrm{O}_{2}}$ of 35 $\mathrm{mm} \mathrm{Hg}$ and $\mathrm{C} \overline{\mathrm{v}}_{\mathrm{O}_{2}}$ of 18.2 volumes $/ 100 \mathrm{ml}$ for subject IV-1. Cardiac output studies were not performed on subject IV-2, but other parameters were within normal limits (Table III). Mixed venous oxygen pressures of $34-35 \mathrm{~mm} \mathrm{Hg}$ were somewhat lower than the $39-40 \mathrm{~mm} \mathrm{Hg}$ reported for normal subjects under comparable circumstances (12). A decreased intercapillary diffusion distance in the tissues would allow adequate oxygen supply at lower than normal mean capillary $\mathrm{Po}_{2}$, but no studies of tissue capillarity were performed. Significant elevations of hematocrit, hemoglobin concentration, and red cell mass have been documented in these subjects who were without clinical illness (2).

\section{Discussion}

The extremely high oxygen affinity of isolated hemoglobin Yakima is comparable to that found in Bart's hemoglobin (13) and in hemoglobin $\mathrm{H}$ (14). The oxygen affinity of blood containing hemoglobin Yakima is higher than that of any human blood previously recorded, including hemoglobin Chesapeake which was also accompanied by an erythrocytosis (15).

Cellular oxygen supply requires the integrated action of several physiologic variables and a change in any of these without associated compensatory responses will produce a change in the rate of oxygen delivery. Haldane, as quoted by Roughton, postulated that a blood oxygen-hemoglobin equilibrium curve shaped and positioned like that of myoglobin would be incompatible with human life (16). Our subjects with hemoglobin Yakima have a functional defect in one identifiable link in the oxygen-delivery chain based upon the high affinity of their blood for oxygen. As oxygen is delivered to tissues, the fall of blood oxygen pressure will be more pronounced in blood with hemoglobin Yakima than in human blood with normal hemoglobin and may reach levels that, in accordance with Haldane's observations, would jeopardize oxygen delivery to intracellular sites of utilization. Compensatory adjustments, which would help to maintain the $\mathrm{Po}_{2}$ in capillary blood at normal levels, include an increase in hemoglobin concentration and an increased rate of blood flow. 


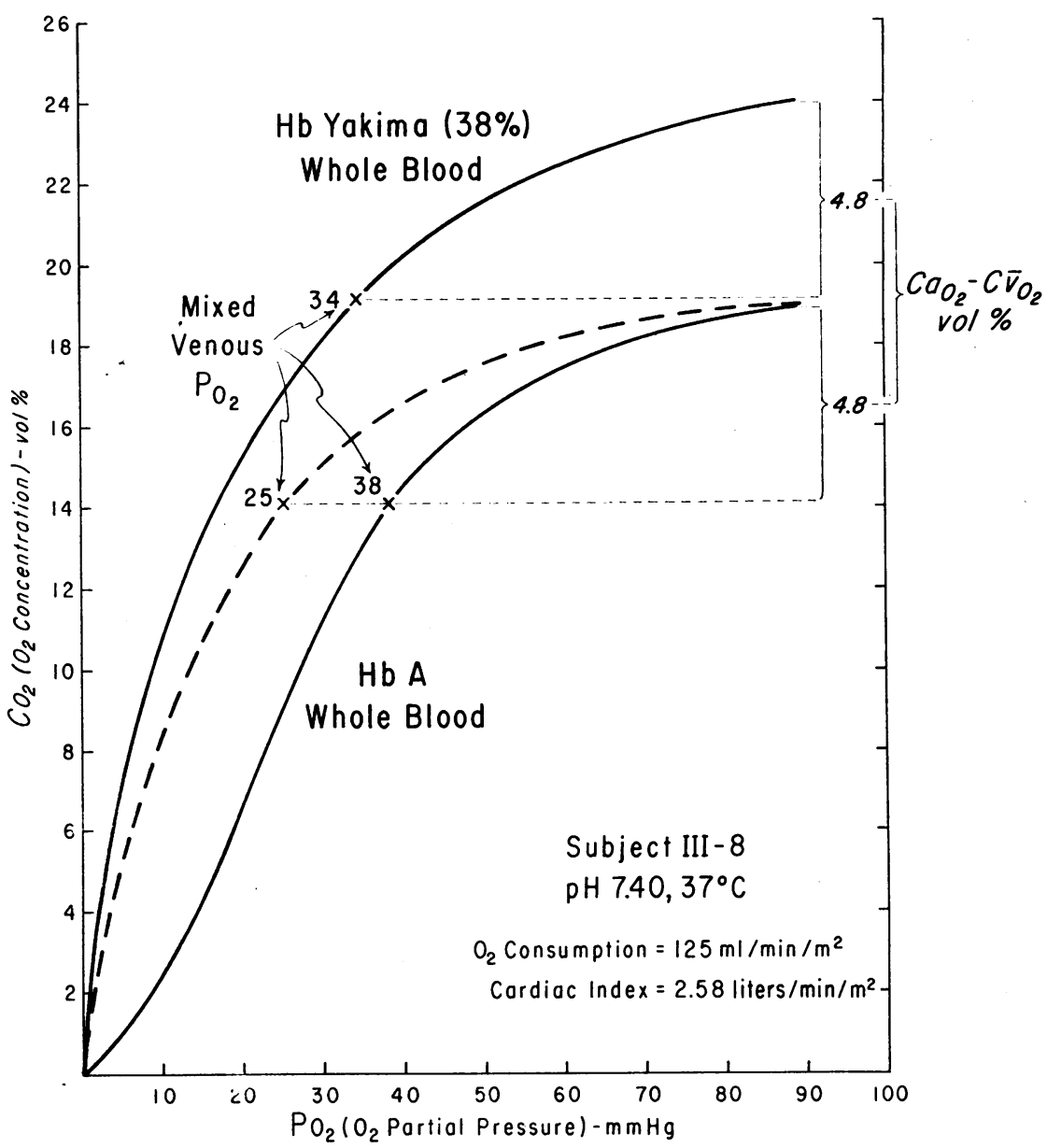

Fig. 3. COMPARISON OF OXYGEN-HEMOGLOBIN EQUILIBRIA OF NORMAL ADULT BLOOD AND BLOOD OF THE PROPOSITUS TO ILLUSTRATE THE EFFECT OF OXYGEN AFFINITY AND OXYGEN-CARRYING CAPACITY ON MIXED veNOUS $\mathrm{Po}_{2}$. The ordinate is expressed as $\mathrm{O}_{2}$ concentration (volumes per $100 \mathrm{ml}$ ) rather than the usual per cent of $\mathrm{O}_{2}$ saturation. The resting arterial-venous $\mathrm{O}_{2}$ concentration difference in volumes per $100 \mathrm{ml}\left(\mathrm{Ca}_{\mathrm{o}_{2}}-\right.$ $\mathrm{C}_{\mathbf{v}_{\mathbf{2}}}$ ) of the propositus is shown. The curve of interrupted lines represents blood with 38\% hemoglobin Yakima and a hypothetical oxygen-carrying capacity of 19.6 volumes $/ 100 \mathrm{ml}$.

The net effect of an increased oxygen-carrying capacity is to increase venous $\mathrm{Po}_{2}$ for a given extraction of oxygen from blood. In Fig. 3 we have illustrated by the dashed line the hypothetical fall of $\mathrm{PO}_{2}$ in subject III- 8 with the same arterialvenous oxygen concentration difference, as calculated from our studies, but without a compensatory erythrocytosis. A mixed venous $\mathrm{Po}_{2}$ of $25 \mathrm{~mm} \mathrm{Hg}$ would be observed under those circumstances. This is in contrast to the value of $34-35 \mathrm{~mm} \mathrm{Hg}$ calculated from our studies in the presence of erythrocytosis. Oxygen consumption in our subjects was normal and no increase in cardiac output at rest above normal values was found. The low resting heart rates, however, suggest that considerable cardiac reserve would be available during exercise.

It is noteworthy that the over-all increase in the red cell mass in these patients is associated with high normal values of urinary erythropoietin activity as studied and interpreted as compatible with a secondary erythrocytosis by Adamson. ${ }^{1}$ The normal arterial oxygen pressures observed in our subjects suggest that the erythropoietin pro-

\footnotetext{
1 Adamson, J. 1966. Personal communication.
} 
duction system is responsive to oxygen pressures in postarterial sites.

Under normal circumstances, oxygen delivery to the fetus is facilitated by an increased oxygen affinity of fetal blood in comparison to maternal blood. Since hemoglobin Yakima is a $\beta$-chain variant, we would not expect this hemoglobin to occur in utero in a significant amount. During pregnancy, in carriers of hemoglobin Yakima, the usual relationship between oxygen affinity of maternal and fetal blood would probably be reversed. Our estimates of transplacental oxygen pressure gradients from available data (17) suggest that in addition to an elevated hemoglobin concentration in maternal blood, an increase in maternal uterine blood flow, and (or) an increase in placental diffusing capacity would be necessary for adequate oxygen transfer to the fetus.

The shape and position of the oxygen-hemoglobin equilibrium curve in these subjects would be expected to show less reserve of $\mathrm{Po}_{2}$ in anemia, in exercise, and in tissues with a high degree of oxygen extraction, e.g., myocardium. However, all three subjects with hemoglobin Yakima and erythrocytosis are active and healthy, which would indicate the benefit of a high blood oxygen-carrying capacity, and possibly other as yet unidentified compensatory mechanisms.

\section{Acknowledgments}

We are indebted to Dr. Edward N. Peterson for his early contributions to this project and to Dietrun Kamp, Gene Welch, Margaret Curtiss, and Susan Groat for technical assistance.

\section{References}

1. Jonxis, J. H. P. 1966. The hemoglobinopathies. In Advances in Pediatrics. S. Z. Levine, editor. Year Book Medical Publishers, Inc., Chicago. 14: 91.

2. Jones, R. T., E. E. Osgood, B. Brimhall, and R. D. Koler. 1967. Hemoglobin Yakima: I. Clinical and biochemical studies. J. Clin. Invest. 46: 1840.

3. Parer, J. T., A. S. Hoversland, and J. Metcalfe. 1967. Some respiratory characteristics of the blood of the adult and young African pygmy goat. J. Appl. Physiol. 22 : 756.
4. Edwards, M. J., and R. J. Martin. 1966. Mixing technique for the oxygen-hemoglobin equilibrium and Bohr effect. J. Appl. Physiol. 21 : 1898.

5. Drabkin, D. L., and J. H. Austin. 1932. Spectrophotometric studies: spectrophotometric constants for common hemoglobin derivatives in human, dog and rabbit blood. J. Biol. Chem. 98 : 719.

6. Paul, W. D., and C. R. Kemp. 1944. Methemoglobin: a normal constituent of blood. Proc. Soc. Exptl. Biol. Med. 56: 55.

7. Kinsman, J. M., J. W. Moore, and W. F. Hamilton. 1929. Studies on the circulation. I. Injection method: physical and mathematical considerations. Am. J. Physiol. 89 : 322.

8. Boicourt, O. W., R. P. Lewis, J. D. Bristow, and H. E. Griswold. 1966. Abnormalities of total body oxygen consumption in valvular heart disease. J. Appl. Physiol. $21: 920$.

9. Scholander, P. F. 1947. Analyzer for accurate estimation of respiratory gases in one-half cubic centimeter samples. J. Biol. Chem. 167: 235.

10. Nechtman, C. M., and T. H. J. Huisman. 1964. Comparative studies of oxygen equilibria of human adult and cord blood red cell hemolyzates and suspensions. Clin. Chim. Acta. 10: 165.

11. Darling, R. C., and F. J. W. Roughton. 1942. The effect of methemoglobin on the equilibrium between oxygen and hemoglobin. Am. J. Physiol. 137: 56.

12. Bartels, H., R. Beer, E. Fleischer, H. J. Hoffheinz, J. Krall, G. Rodewald, J. Wenner, and I. Witt. 1955. Bestimmung von Kurzschlussdurchblutung und Diffusionskapazität der lunge bei Gesunden * und Lungenkranken. Arch. Ges. Physiol. 261: 99.

13. Horton, B. F., R. B. Thompson, A. M. Dozy, C. M. Nechtman, E. Nichols, and T. H. J. Huisman. 1962. Inhomogeneity of hemoglobin. VI. The minor hemoglobin components of cord blood. Blood. 20: 302.

14. Benesch, R. E., H. M. Ranney, R. Benesch, and G. M. Smith. 1961. The chemistry of the Bohr effect. II. Some properties of hemoglobin $\mathrm{H}$. J. Biol. Chem. 236: 2926.

15. Charache, S., D. J. Weatherall, and J. B. Clegg. 1966. Polycythemia associated with a hemoglobinopathy. J. Clin. Invest. $45: 813$.

16. Roughton, F. J. W. 1964. Transport of oxygen and carbon dioxide. In Handbook of Physiology. Respiration, Section 3. W. O. Fenn and H. Rahn, editors. American Physiological Society, Washington. $1: 775$.

17. Metcalfe, J., H. Bartels, and W. Moll. 1967. Gas exchange in the pregnant uterus. Physiol. Rev. In press. 